Article

\title{
Protective Effects of Irbesartan, an Angiotensin Receptor Blocker with PPAR $\gamma$ Agonistic Activity, against Estradiol Benzoate-Induced Endometrial Hyperplasia and Atypia in Female Rats via Modulation of TNF $\alpha /$ Survivin Pathway
}

\author{
Mohamed A. Morsy ${ }^{1,2, *(\mathbb{D})}$, Wedad M. Abdelraheem ${ }^{3} \mathbb{D}$, Maram El-Hussieny ${ }^{4}$ and Marwa M. M. Refaie ${ }^{2}$ \\ 1 Department of Pharmaceutical Sciences, College of Clinical Pharmacy, King Faisal University, \\ Al-Ahsa 31982, Saudi Arabia \\ 2 Department of Pharmacology, Faculty of Medicine, Minia University, El-Minia 61511, Egypt; \\ marwamonier@yahoo.com \\ 3 Department of Medical Microbiology and Immunology, Faculty of Medicine, Minia University, \\ El-Minia 61511, Egypt; altaqwa.2012@yahoo.com \\ 4 Department of Pathology, Faculty of Medicine, Minia University, El-Minia 61511, Egypt; \\ sama_feb.2009@yahoo.com \\ * Correspondence: momorsy@kfu.edu.sa; Tel.: +966-5496-72245
}

check for updates

Citation: Morsy, M.A.; Abdelraheem, W.M.; El-Hussieny, M.; Refaie, M.M.M. Protective Effects of Irbesartan, an Angiotensin Receptor Blocker with PPAR $\gamma$ Agonistic Activity, against Estradiol Benzoate-Induced Endometrial Hyperplasia and Atypia in Female Rats via Modulation of $\mathrm{TNF} \alpha /$ Survivin Pathway. Pharmaceuticals 2021, 14, 649. https://doi.org/10.3390/ph14070649

Academic Editor: Carlo Marchetti

Received: 19 May 2021

Accepted: 1 July 2021

Published: 6 July 2021

Publisher's Note: MDPI stays neutral with regard to jurisdictional claims in published maps and institutional affiliations.

Copyright: (c) 2021 by the authors. Licensee MDPI, Basel, Switzerland. This article is an open access article distributed under the terms and conditions of the Creative Commons Attribution (CC BY) license (https:// creativecommons.org/licenses/by/ $4.0 /)$.

\begin{abstract}
Endometrial hyperplasia $(\mathrm{EH})$ is a common gynecological problem and may progress to carcinoma. Early detection and management of EH are mandatory for the prevention of endometrial cancer. Activation of the renin-angiotensin system and angiotensin II signaling are involved in the progression of precancerous and cancerous lesions. However, no studies have evaluated the role of this system in estradiol benzoate (EB)-induced EH and atypia. Irbesartan (IRB), an angiotensin II receptor blocker with peroxisome proliferator-activated receptor gamma (PPAR $\gamma$ ) agonistic activity was administered $(30 \mathrm{mg} / \mathrm{kg} / \mathrm{d})$ in EB-treated $(60 \mu \mathrm{g} / 100 \mathrm{~g}$ bodyweight, intramuscularly, three times per week) or untreated rats for 4 weeks. Uterine weight changes, malondialdehyde, superoxide dismutase (SOD), tumor necrosis factor-alpha (TNF $\alpha$ ), survivin, cleaved caspase 3, interleukin-10 (IL10), and PPAR $\gamma$ were measured in addition to undergoing histopathological examination. Results showed that EB-induced EH and atypia significantly increased the uterine body weight, malondialdehyde, TNF $\alpha$, and survivin, accompanied with significantly decreased SOD, cleaved caspase 3, IL10, and PPAR $\gamma$, with typical histopathological changes of EH and atypia. Coadministration of IRB significantly prevented EB-induced biochemical and histopathological changes. The protective effects of IRB may be attributed to its anti-inflammatory and antioxidant properties, reduction of survivin, and increased levels of cleaved caspase 3.
\end{abstract}

Keywords: endometrial hyperplasia; irbesartan; estradiol benzoate; tumor necrosis factor-alpha; survivin; cleaved caspase 3; interleukin-10; peroxisome proliferator-activated receptor gamma

\section{Introduction}

Endometrial hyperplasia $(\mathrm{EH})$ is a significant gynecological problem, especially during childbearing age. It is a uterine pathology representing several morphological and endometrial changes. The hyperplastic changes originate from the uterine endometrial glands with an increase in the gland-to-stroma ratio compared with the regular endometrium. Unfortunately, about $40 \%$ of EH patients with atypia develop carcinoma, the most common fatal gynecological malignancy [1]. The revised 2014 WHO classification divides EH into two categories: (1) hyperplasia without atypia and (2) atypical hyperplasia, based upon the presence or absence of cytological atypia [2]. Hyperplasia without atypia is not associated with relevant genetic changes. However, about $1-3 \%$ of the cases progress to invasive cancer under the influence of prolonged estrogen exposure, especially if accompanied by 
relative progesterone insufficiency. Atypical EH exhibits mutations, which are typical for invasive endometrioid adenocarcinoma [2,3].

Suppression of apoptotic signaling pathways, including caspase 3 cascade, by increased estrogen levels, contributes to the development of $\mathrm{EH}$ and endometrial cancer (EC). Apoptotic cell death usually protects against DNA replication and repair errors, and somatic mutations. Thus, suppression of such protective mechanisms promotes $\mathrm{EH}$, and subsequent malignancy [4]. The unopposed estrogen-mediated signaling in the endometrium increases inflammation via the release of the pro-inflammatory agents [5]. Moreover, induction of inflammation contributes to the initiation and progression of the disease via the release of interleukins (ILs), growth factors, and cytokines to facilitate immune cell recruitment and cell proliferation with sustained tumor growth [6]. One of the essential pro-inflammatory cytokines is tumor necrosis factor-alpha (TNF $\alpha)$ that induces the excessive formation of free radicals, rapid cell division, and DNA damage [4].

The imbalance between oxidative and antioxidant pathways is pivotal to the hyperplastic and cancerous changes in the endometrium. This imbalance starts and maintains an abnormal inflammatory state by activating pro-inflammatory cytokines such as TNF $\alpha$. Subsequent activation and translocation of the transcription factor nuclear factor-kappa $\mathrm{B}$ (NF- $\mathrm{KB}$ ) to the nucleus increases the expression of survivin, an inhibitor of the apoptotic process, upregulation of anti-apoptotic genes, excessive cell proliferation, differentiation, hyperplasia, and dysplasia [7,8]. Moreover, the inhibitor of apoptosis proteins (IAPs) can positively modulate NF- $\mathrm{KB}$ signaling to further support cell survival and tumorigenesis. Previous studies demonstrated the ability of c-IAP1 and c-IAP2 to interact with TNF receptor 1 and augment TNF $\alpha$-stimulated NF- $\mathrm{kB}$ activation. Furthermore, the survivinXIAP complex activates NF- $\mathrm{kB}$, promoting further transcription of both growth and antiapoptotic genes [9]. On the other hand, the anti-inflammatory cytokine interleukin-10 (IL10) opposes the $\mathrm{TNF} \alpha / \mathrm{NF}-\mathrm{kB} /$ oxidative stress axis that is essential to endometrial hyperplasia and carcinogenesis. IL10 acts as an antitumor cytokine by inhibiting the NF- $\mathrm{KB}$-induced pro-inflammatory cytokine expression. Furthermore, IL10 ameliorates the TNF $\alpha$-induced reduction of superoxide dismutase (SOD) and increased lipid peroxidation $[8,10]$.

Dysregulation of the endometrial renin-angiotensin system could predispose to $\mathrm{EH}$ and EC [11,12]. Previous studies implicated angiotensin II (AngII) and AngII type 1 receptor (AT1R) in the development of EC [13-16]. The ability of telmisartan, an AT1R blocker and a peroxisome proliferator-activated receptor gamma (PPAR $\gamma$ ) agonist, to inhibit EC cell proliferation and tumor growth in nude mice adds further evidence to such hypotheses [17]. AngII-mediated activation of survivin signaling could explain its effect on tumor progression [18]. On the other hand, activation of PPAR $\gamma$ decreases the gene expression of survivin [19]. Survivin, which is widely expressed in different precancerous lesions and cancers, promotes cell survival and inhibits apoptosis [9]. Thus, drugs that could antagonize survivin hold promise for treating many forms of cancer [20,21]. Therefore, the aim of the present work was to investigate the probable protective mechanisms of the AT1R blocker with PPAR $\gamma$ agonistic activity irbesartan (IRB) against estradiol benzoate (EB)-induced EH and atypia in rats.

\section{Results}

\subsection{Effect of IRB on Uterine Weight, Malondialdehyde (MDA), and SOD}

MDA level and SOD activity were measured as markers of uterine oxidative stress. The EH-induced group showed a significant increase in uterine weights and MDA levels and a significant decrease in SOD activities compared to the normal control group. In contrast, the administration of IRB showed a significant decrease in uterine weights and MDA levels and a significant increase in SOD activities compared to the EH-induced group (Table 1). 
Table 1. Effect of irbesartan (IRB) on uterine weights, malondialdehyde (MDA), and superoxide dismutase (SOD) in estradiol benzoate-induced endometrial hyperplasia (EH) and atypia in rats.

\begin{tabular}{cccc}
\hline Group & $\begin{array}{c}\text { Uterine Weight } \\
\text { (g) }\end{array}$ & $\begin{array}{c}\text { MDA } \\
\text { (nmol/g Tissue) }\end{array}$ & $\begin{array}{c}\text { SOD } \\
\text { (U/g Tissue) }\end{array}$ \\
\hline Control & $1.0 \pm 0.05$ & $27.0 \pm 2.7$ & $3701 \pm 374$ \\
IRB & $0.9 \pm 0.05$ & $26.7 \pm 2.4$ & $4050 \pm 275$ \\
EH & $5.3 \pm 0.20^{\mathrm{a}}$ & $87.2 \pm 5.2^{\mathrm{a}}$ & $1440 \pm 150^{\mathrm{a}}$ \\
EH + IRB & $2.0 \pm 0.06^{\mathrm{ab}}$ & $33.7 \pm 2.1^{\mathrm{b}}$ & $2463 \pm 238^{\mathrm{ab}}$
\end{tabular}

At the end of the experiment (4 weeks), uterine weight changes, MDA, and SOD were determined. Values are mean $\pm \operatorname{SEM}(n=6-7) .{ }^{\mathrm{a}, \mathrm{b}}$ Significantly different $(p<0.05)$ from control and EH groups, respectively.

\subsection{Histopathological and Immunohistochemical Evaluation}

\subsubsection{Macroscopic Examination}

Uteri of control and IRB groups had no macroscopic abnormalities. There was marked dilation of the uterine horns in the EH group containing a thick turbid fluid. Uteri of the $\mathrm{EH}+\mathrm{IRB}$ group had less uterine horn dilation than observed in the EH group and contained only serous fluid.

\subsubsection{Histopathological Evaluation}

Examination of control and IRB groups (Figure 1a,b; Table 2) revealed no histopathological abnormalities; surface and glandular epithelium were low cuboidal with fine eosinophilic cytoplasm and central regular nuclei. No glandular crowdedness with abundant endometrial stroma in between the glands. The EH group (Figure 1c; Table 2) showed EH features, as there were crowded irregularly shaped glands. The epithelial lining showed hypertrophy and stratification. Focal atypical EH was detected in variable areas. The irregularly shaped glands were compact together, with almost no stroma in between. Nuclei were vesicular, exhibiting atypical features with loss of polarity, anisonucleosis, and prominent nucleoli. The EH+IRB group (Figure 1d; Table 2) showed a picture suggestive of almost normal-looking disordered endometrial glands; few were cystic. The lining epithelium was low columnar with no features of EH.

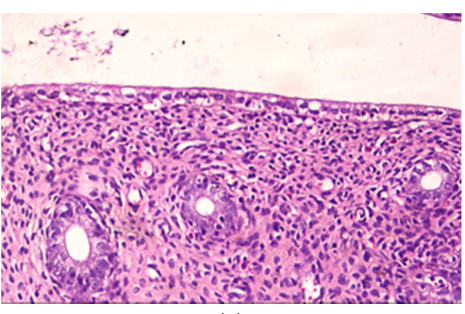

(a)

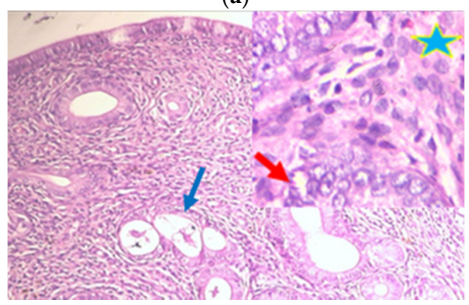

(c)

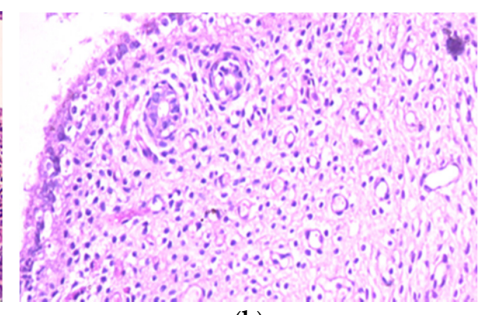

(b)

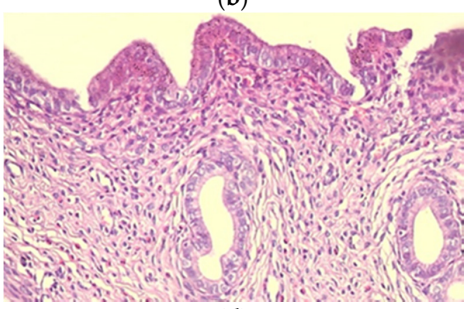

(d)

Figure 1. Effect of irbesartan (IRB) on histopathological changes in estradiol benzoate-induced endometrial hyperplasia (EH) and atypia in rats (hematoxylin and eosin, $\times 200$; ( $n=7$ /group). $(\mathbf{a}, \mathbf{b})$ Control and IRB groups, respectively, reveal no histopathological abnormalities. (c) In the EH group, the epithelial lining shows hypertrophy and stratification (blue arrow). The insert $(\times 400)$ shows vesicular nuclei exhibiting atypical features with loss of polarity, anisonucleosis, and prominent nucleoli (red arrow), and the stomas show excessive leukocytic infiltration (asteroid). (d) The $\mathrm{EH}+\mathrm{IRB}$ group shows a picture suggestive of almost normal-looking disordered endometrial glands, and the lining epithelium was low columnar. 
Table 2. Effect of irbesartan (IRB) on the severity of histopathological lesions in estradiol benzoateinduced endometrial hyperplasia $(\mathrm{EH})$ and atypia in rats.

\begin{tabular}{ccccc}
\hline Group & $\begin{array}{c}\text { Glandular } \\
\text { Irregularity and } \\
\text { Crowdedness }\end{array}$ & $\begin{array}{c}\text { Epithelial } \\
\text { Hypertrophy and } \\
\text { Stratification }\end{array}$ & $\begin{array}{c}\text { Focal Atypical } \\
\text { Cellular } \\
\text { Changes }\end{array}$ & $\begin{array}{c}\text { Leukocytic Cell } \\
\text { Infiltration }\end{array}$ \\
\hline Control & - & - & - & + \\
IRB & - & - & - & + \\
EH & +++ & +++ & +++ & +++ \\
EH + IRB & + & + & - & ++ \\
\hline
\end{tabular}

Score (-) is considered no change. Scores $(+),(++)$, and (+++) are mild, moderate, and severe changes.

\subsubsection{Evaluation of $\mathrm{TNF} \alpha$ (Immunohistochemistry and ELISA)}

To evaluate the effect of IRB on the inflammatory pathway, the level of the uterine expression of the pro-inflammatory cytokine TNF $\alpha$ was evaluated. There was grade 1 ( $\leq 25 \%$ stained cells) TNF $\alpha$ expression in control, IRB, and EH+IRB groups (Figure 2a,b,d). On the other hand, the EH group showed grade 4 (>75\% stained cells) TNF $\alpha$ expression (Figure 2c). Semiquantitative densitometrical analysis of uterine sections showed that $\mathrm{TNF} \alpha$ expression was significantly higher in the EH group compared to the control group and significantly lower in the EH+IRB group compared to the EH group (Figure 2e). The same pattern was seen with the TNF $\alpha$ level measured with ELISA kit (Figure 2f).

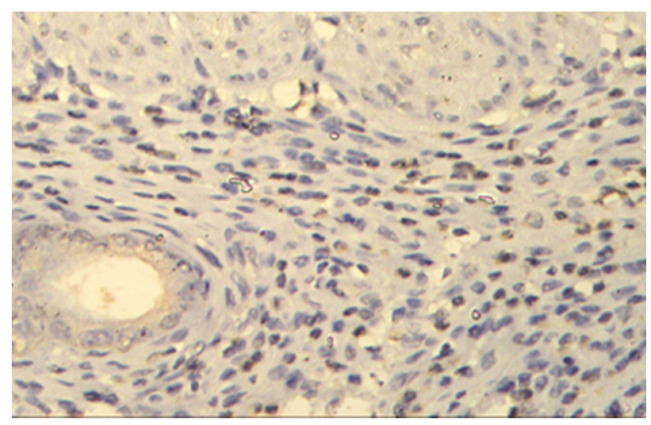

(a)

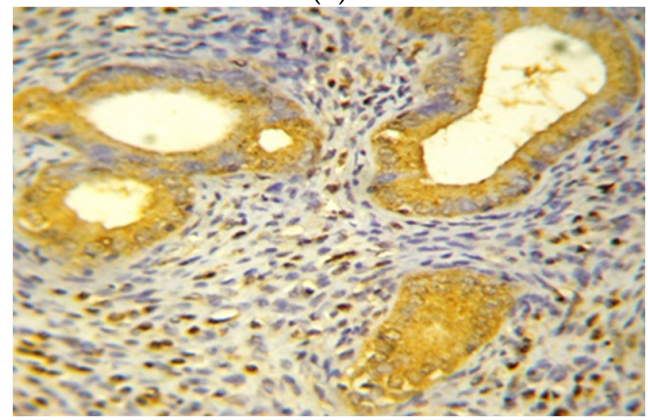

(c)

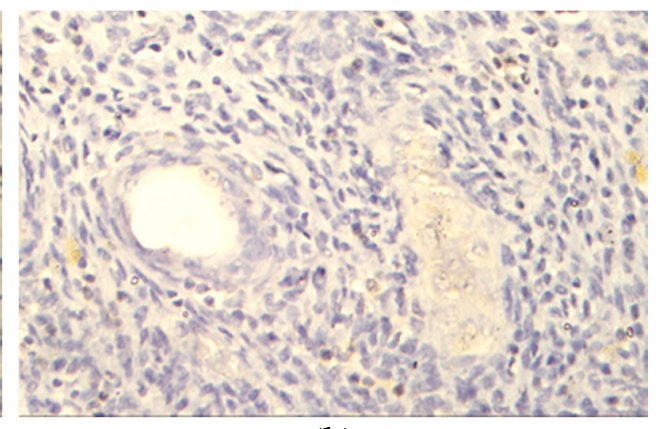

(b)

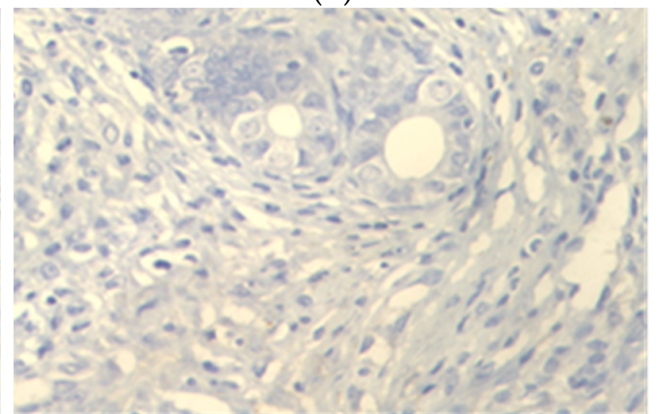

(d)

Figure 2. Cont. 


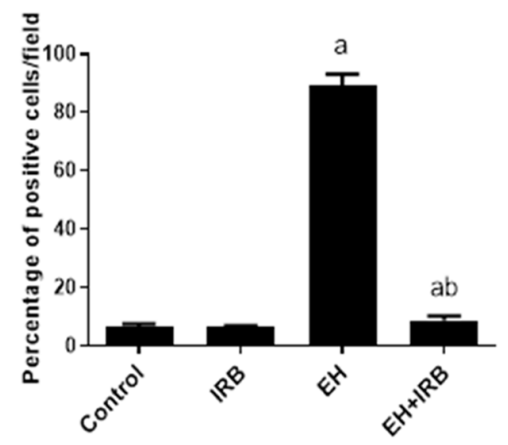

(e)

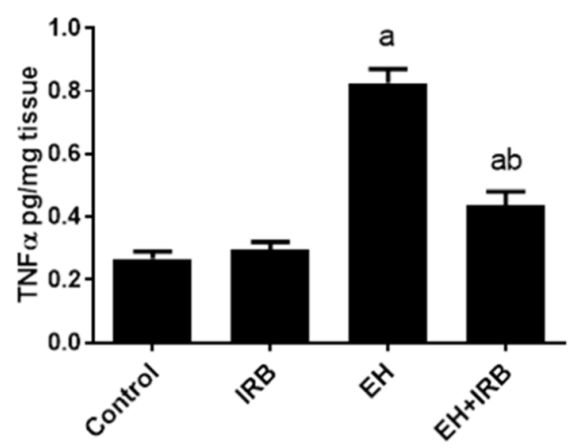

(f)

Figure 2. Effect of irbesartan (IRB) on uterine tumor necrosis factor-alpha (TNF $\alpha$ ) in estradiol benzoate-induced endometrial hyperplasia $(\mathrm{EH})$ and atypia in rats. Images are from representative sections of the rat uterus $(\times 400)$ stained for detection of TNF $\alpha$ in (a) control, (b) IRB-treated, (c) EH, and (d) $\mathrm{EH}+$ IRB-treated groups. A semiquantitative analysis of $\mathrm{TNF} \alpha$ expression (percent of $\mathrm{TNF} \alpha$ positive cells / field) (e), as well as the protein levels of uterine TNF $\alpha$ level (pg/mg tissue) as determined by ELISA (f), are shown. Results represent the mean \pm SEM $(n=6-7)$. ${ }^{a}, \mathrm{~b}$ Significantly different $(p<0.05)$ from control and EH groups, respectively.

\subsubsection{Evaluation of Survivin Expression}

To evaluate the effect of IRB on the cell-survival pathway, the level of the uterine expression of an inhibitor of apoptosis survivin was measured. Negative survivin expression was observed in control, IRB, and EH+IRB groups (Figure 3a,b,d). In contrast, the EH group showed positive survivin expression (Figure 3c). Semiquantitative densitometrical analysis showed that survivin expression was significantly higher in the EH group compared to the control group and significantly lower in the EH+IRB group compared to the EH group (Figure 3e).

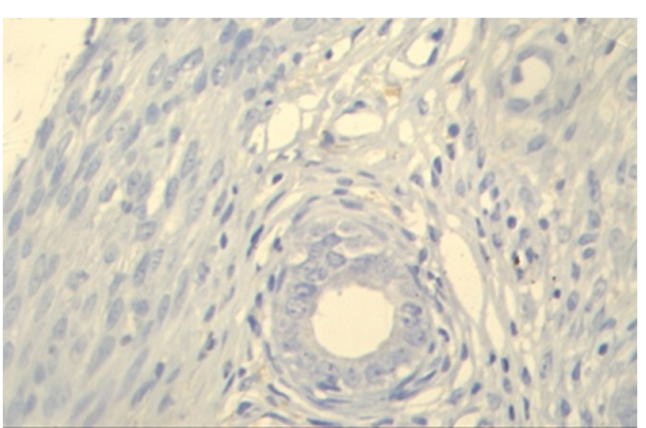

(a)

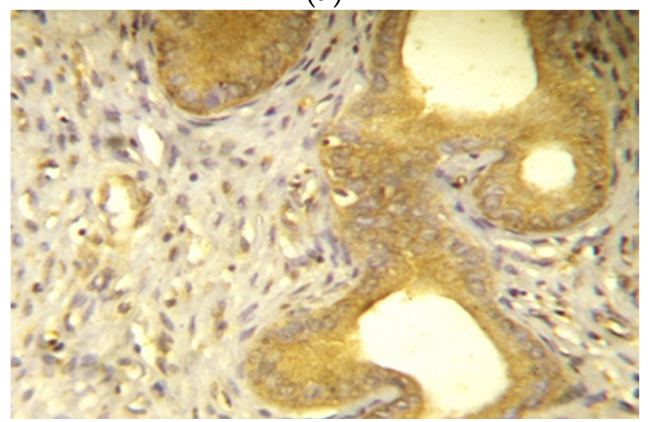

(c)

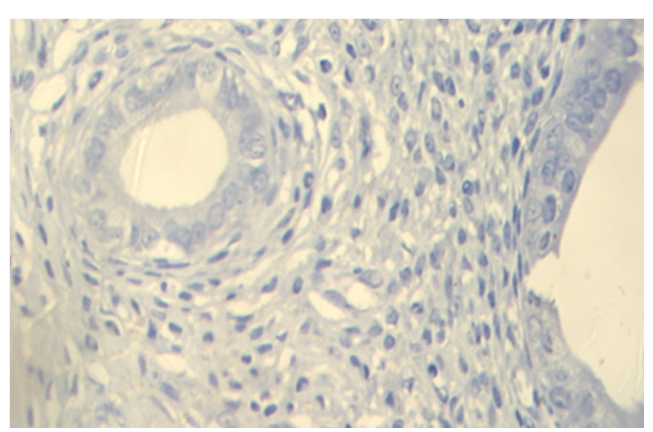

(b)

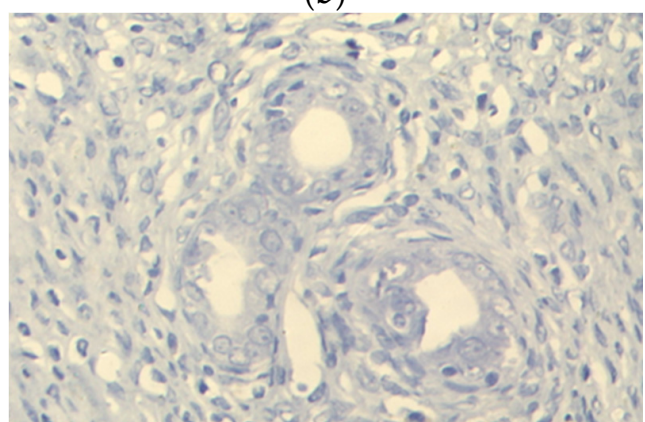

(d)

Figure 3. Cont. 


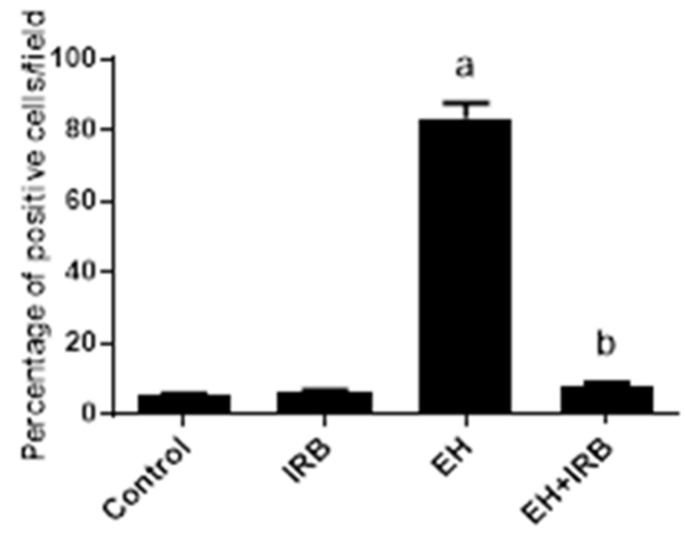

(e)

Figure 3. Effect of irbesartan (IRB) on uterine survivin immunohistochemical staining in estradiol benzoate-induced endometrial hyperplasia $(\mathrm{EH})$ and atypia in rats. Images are representative sections of the rat uterus $(\times 400)$ stained for detection of survivin in (a) control, (b) IRB-treated, (c) EH, and (d) EH+IRB-treated groups. Semiquantitative analysis of survivin expression in different groups was carried out (e). Results represent the mean \pm SEM $(n=6-7)$ of the percentage of survivin positive cells/field. ${ }^{\mathrm{a}, \mathrm{b}}$ Significantly different $(p<0.05)$ from control and EH groups, respectively.

\subsubsection{Evaluation of Cleaved Caspase 3 Expression}

Negative cleaved caspase 3 expression was observed in control, IRB, and EH groups (Figure $4 \mathrm{a}-\mathrm{c}$ ). Meanwhile, the EH+IRB group showed positive cleaved caspase 3 expression (Figure 4d). Semiquantitative densitometrical analysis showed that cleaved caspase 3 expression was significantly higher in the EH+IRB group compared to control and EH groups (Figure 4e).

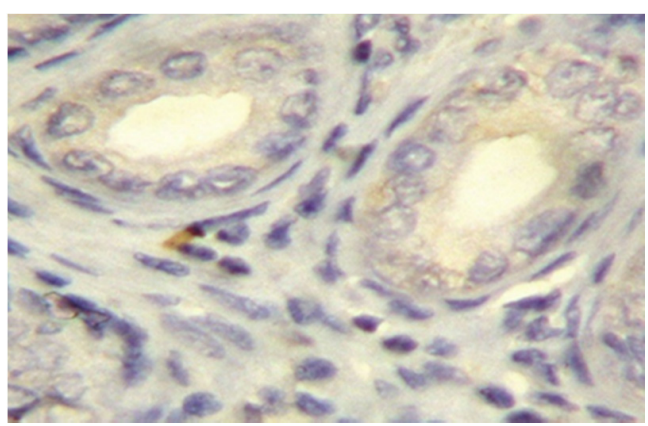

(a)

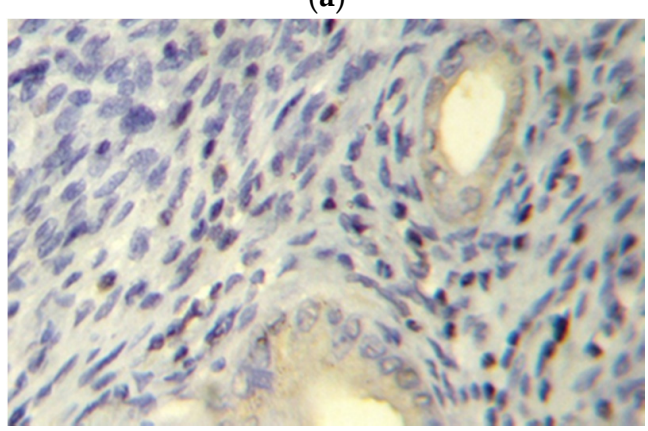

(c)

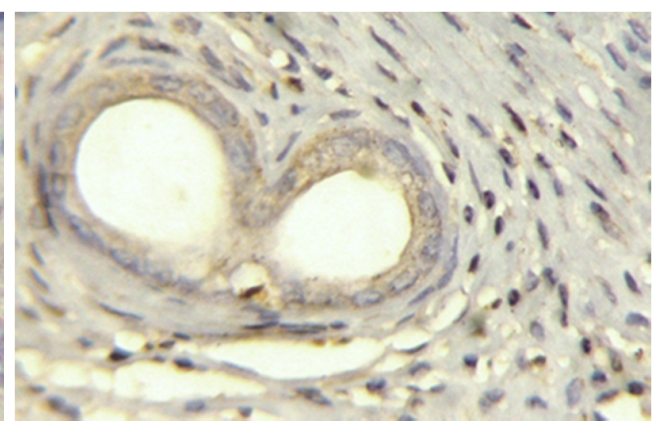

(b)

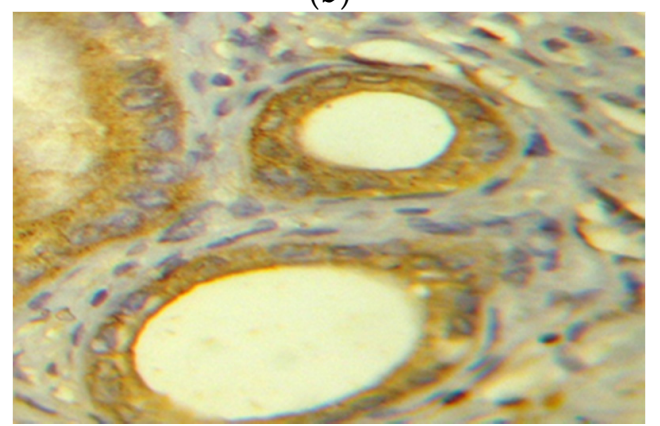

(d)

Figure 4. Cont. 


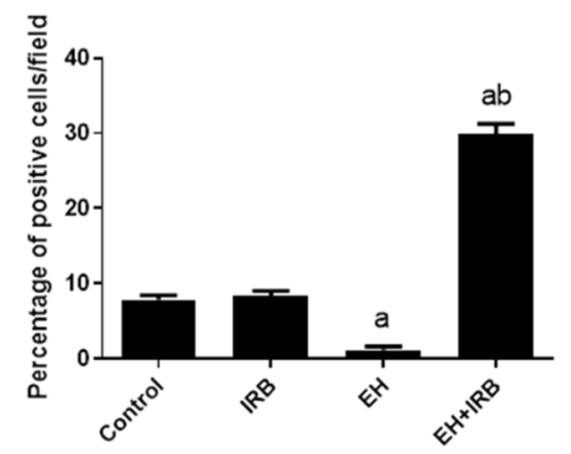

(e)

Figure 4. Effect of irbesartan (IRB) on uterine cleaved caspase 3 immunohistochemical staining in estradiol benzoate-induced endometrial hyperplasia $(\mathrm{EH})$ and atypia in rats. Staining of cleaved caspase 3 in representative sections of rat uterus $(\times 400)$ is shown in (a) control, (b) IRB-treated, (c) $\mathrm{EH}$, and (d) EH+IRB-treated groups. Data in (e) show the results of the semiquantitative analysis of cleaved caspase 3 expression. Data represent the mean \pm SEM $(n=6-7)$ of the percentage of cleaved caspase 3 positive cells / field. ${ }^{\text {a,b }}$ Significantly different $(p<0.05)$ from control and EH groups, respectively.

\subsection{Effect of IRB on IL10 Gene Expression}

Real-time polymerase chain reaction (PCR) was used to quantify the relative expression of the IL10 gene in different groups. Glyceraldehyde-3-phosphate dehydrogenase (GAPDH) was chosen as a reference gene to standardize mRNA expression. The analysis revealed the upregulation of the IL10 gene in the form of 1.1 fold in the IRB group and 1.3fold in the prophylactic group (EH+IRB) compared with the control group. The IL10 gene expression in the EH group was not detected (Figure 5).

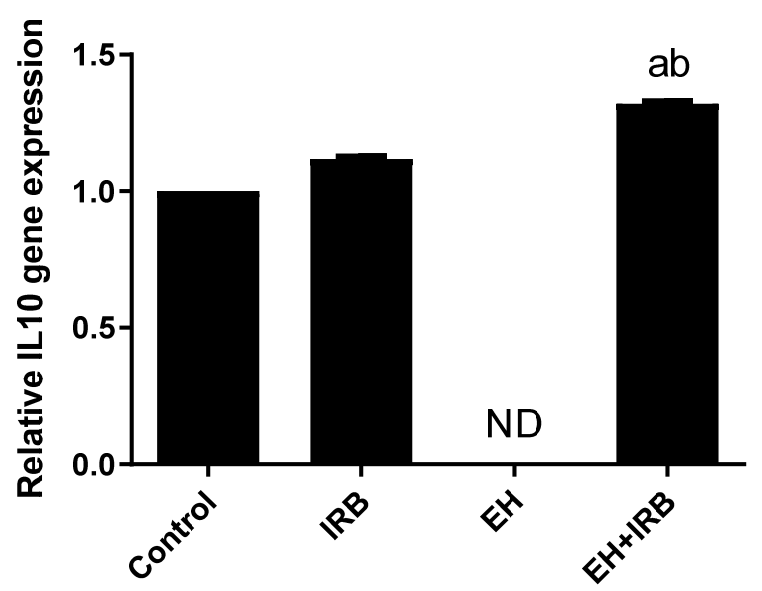

Figure 5. Uterine interleukin-10 (IL10) relative gene expression detected by real-time polymerase chain reaction. Values represent the mean $\pm \operatorname{SEM}(n=6)$. ${ }^{\mathrm{a}, \mathrm{b}}$ Significantly different $(p<0.05)$ from control and EH groups, respectively. IRB: irbesartan; ND: non-detected.

\subsection{Effect of IRB on PPAR $\gamma$ Level}

The EH-induced group showed a significant decrease in uterine PPAR $\gamma$ levels compared to the normal control group. In contrast, the administration of IRB showed a significant increase in uterine PPAR $\gamma$ levels compared to the EH-induced group (Figure 6). 


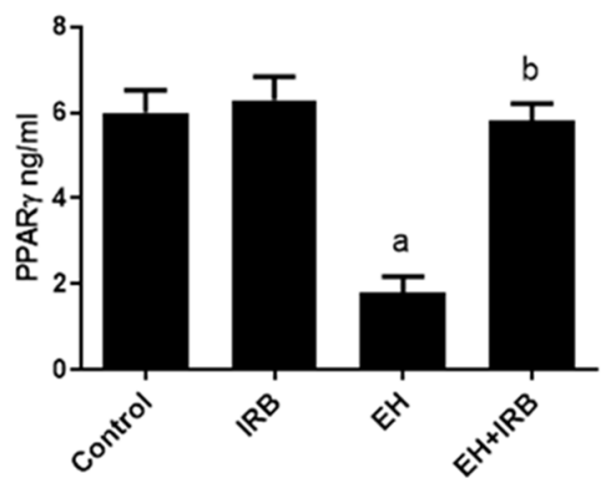

Figure 6. Effect of irbesartan (IRB) on peroxisome proliferator-activated receptor gamma (PPAR $\gamma$ ) in estradiol benzoate-induced endometrial hyperplasia $(\mathrm{EH})$ and atypia in rats. Values are mean \pm SEM $(n=6-7)$. ${ }^{\text {a,b }}$ Significantly different $(p<0.05)$ from control and EH groups, respectively.

\section{Discussion}

Endometrial carcinoma is the most common gynecological malignancy, and EH is its precursor [1]. There is a strong relationship between the renin-angiotensin system and AngII receptors' overexpression, and initiation and progression of EH and EC. Koyama et al. [17] evaluated the PPAR $\gamma$ agonistic effect of telmisartan, another AT1R blocker, as PPAR $\gamma$ induces apoptosis in uterine endometrial carcinoma [22]. This directed our attention to examine the possible unexplored protective mechanisms of IRB, an AT1R blocker with PPAR $\gamma$ agonistic activity [23], in EH. For example, IRB shows anti-inflammatory and antioxidant properties [24-26], two actions that are expected to be efficacious in the prevention of EH. The results showed that EB succeeded in the induction of $\mathrm{EH}$ as evidenced by the significant increase in uterine weights, $\mathrm{MDA}, \mathrm{TNF} \alpha$, survivin with a concomitant decrease in SOD, cleaved caspase 3, IL10, and PPAR $\gamma$, besides typical histopathological features of $\mathrm{EH}$ and atypia. Coadministration of IRB with EB significantly improved the biochemical and histopathological changes seen in the EB group.

Oxidative stress plays an important role in EH. Pejić et al. [27] reported that patients with EH and EC had elevated lipid peroxidation and decreased uterine SOD activities. Estrogen metabolites produce reactive oxygen species capable of inducing peroxidative damage to cellular membranes [28]. In agreement with the present study, previous reports $[29,30]$ showed similar findings relating to the ability of EB to increase the lipid peroxidation product MDA, a known marker of oxidative stress, in EB-induced EH in female rats. Similarly, EB can increase oxidative stress in EH by decreasing the endogenous antioxidant enzyme SOD [29,30]. SOD effectively shields from oxidative stress by dismutation of superoxide radicals to hydrogen peroxide [31]. In the current study, IRB administration afforded protection to the uterus against EB-induced oxidative stress. Consistent with this result, several previous studies demonstrated similar findings relating to the ability of IRB to decrease oxidative stress through a significant reduction in MDA level with a significant increase in SOD activity [24,25], may be partly through AT1R blockade, as Ang II can result in oxidative stress [32], and PPAR $\gamma$ agonistic activity [33].

Inflammation plays an important role in the development and progression of EH [34]. In the present study, EB-induced EH was associated with increased inflammation, evident by increased uterine pro-inflammatory cytokine TNF $\alpha$ and decreased anti-inflammatory cytokine IL10. TNF $\alpha$ can contribute to the pathogenesis of EB-induced EH through induction of oxidative stress [35], generation of angiogenic factors [36], increase estrogen production [37], and activation of NF-kB-induced anti-apoptotic genes (Bcl-2 and survivin), inflammatory responses, and cyclooxygenase-2 [4]. In the present study, the increase in uterine $\mathrm{TNF} \alpha$ is in harmony with the results of Abdelzaher et al. [38] who reported a significant increase in TNF $\alpha$ in estradiol valerate-induced $\mathrm{EH}$ in rats. In contrast, the expression of the IL10 gene did not change in patients with EH [39], although in the current study, EH was associated with decreased IL10 expression. The EH+IRB-treated rats showed 
lower uterine TNF $\alpha$ and enhanced IL10 compared to EH untreated rats. In agreement with these results, IRB decreased TNF $\alpha$ and increased IL10 in cyclophosphamide-induced ovarian damage in rats [40], high salt-induced hypertensive mice [41], and monocyte culture supernatants from hypertensive patients with left ventricular hypertrophy [26]. The anti-inflammatory effect of IRB may be in part due to AT1R blockade [16] and the PPAR $\gamma$ agonistic activity [42].

Survivin, a potent inhibitor of apoptosis, plays an essential role in EH $[43,44]$. He et al. [44] reported an increase in survivin in EB-induced EH, which is in line with the present study results. On the other hand, survivin was significantly lower in the EH+IRB group compared to the EH group. To our best knowledge, the present study is the first to report the effect of AT1R blockade on downregulation of survivin. However, as AngII is known to increase survivin [18,45-48], it is not a surprise it is inhibited by AT1R blocker. Moreover, PPAR $\gamma$ activation, which regulates cell proliferation and apoptosis, resulted in decreased survivin expression [19].

Consistent with the current study, previous reports $[29,49]$ demonstrated similar findings in connection with the ability of EB to decrease cleaved caspase 3, an apoptosis marker, in EB-induced EH in rats. On the other hand, the EH+IRB-treated rats showed higher uterine cleaved caspase 3 compared to $\mathrm{EH}$ untreated rats. Compatible with these results, IRB increased cleaved caspase 3 in IRB-sensitive tumors in CBA mice [50]. The apoptotic effect of IRB may be partly owing to a decrease in survivin that inhibits the apoptotic process via suppressing caspase activities [9].

PPAR $\gamma$ has antiproliferative activity against EH [17] and EC [22]. In the present study, a significant decrease in PPAR $\gamma$ level was noticed in the EH group compared to the control group, while a significant increase in its level was detected in the EH+IRB group compared to the EH group. This reflects that PPAR $\gamma$ deficiency can be a contributing factor in mediating the pathogenesis of EH. As mentioned above, the PPAR $\gamma$-mediated inhibition of EH can be due to a decrease in oxidative stress [33], inflammation [42], survivin [19], and an increase in cleaved caspase 3 [17]. In addition, PPAR $\gamma$ activation mediates IRB-induced adiponectin upregulation [51], which was found to be linked with decreased EC risk [52].

Finally, compatible with previous reports $[29,30]$, the current study showed the characteristic histopathological changes of EB-induced EH and atypia. On the other hand, IRB was able to prevent the damage produced by EB administration, thus providing further support to the suggestive mechanism of action of IRB. Taken together, the protective effects of IRB against EB-induced EH and atypia may be mediated via anti-inflammatory (by modulating the pro-inflammatory cytokine TNF $\alpha$ and the anti-inflammatory cytokine IL10) and antioxidant (by modulating MDA and SOD) pathways, and possibly the reduction of survivin and increase in cleaved caspase 3 and PPAR $\gamma$.

\section{Materials and Methods}

\subsection{Chemicals}

IRB was from Sanofi Egypt (Cairo, Egypt). EB was from Misr Pharma (Qaliubiya, Egypt). Polyclonal rabbit/anti-rat $\mathrm{TNF} \alpha$, survivin, and cleaved caspase 3 antibodies, biotinylated goat anti-rabbit secondary antibody (staining detection kit), TNF $\alpha$ ELISA kit, and quantitative real-time PCR kit were from Thermo Fisher Scientific (Waltham, MA, USA). PPAR $\gamma$ ELISA kit was from MyBioSource (San Diego, CA, USA).

\subsection{Animals and Experimental Design}

Adult female Wistar rats weighing 250-300 g were obtained from National Research Center (Giza, Egypt). Animals were kept in standard housing conditions in cages, 3 rats/cage, and left to acclimatize for one week. Rats were supplied with laboratory chow and tap water. This work was conducted in the Pharmacology Department, Faculty of Medicine, Minia University, Egypt, and the animal experimental protocol was approved (716:12/2020) by the Institutional Research Ethics Committee. 
Rats were randomly assigned into 4 groups ( $n=7$ each). Group I received the vehicles (1\% carboxymethylcellulose orally/day and intramuscular (i.m.) injection of olive oil 3 times/week) for 4 weeks. Group II received an oral daily dose of IRB (30 mg/kg) [53] and an i.m. injection of olive oil (3 times/week) for 4 weeks. Group III received 1\% carboxymethylcellulose orally/day and i.m. injection of EB (60 $\mu \mathrm{g} / 100 \mathrm{~g} ; 3$ times/week) for 4 weeks [44]. Group IV received an oral daily dose of IRB (30 mg/kg) plus i.m. injection of EB (60 $\mu \mathrm{g} / 100 \mathrm{~g}$; 3 times/week) for 4 weeks.

\subsection{Preparation of Uterine Homogenate}

At the end of the experiment, animals were weighed and euthanized. Each uterus was weighed, and part of the uterus was kept at $-80^{\circ} \mathrm{C}$. Another part of the uterus was used to prepare tissue homogenate, for biochemical analysis, in $20 \% \mathrm{w} / \mathrm{v}$ in ice-cold phosphate buffer (0.01 M, pH 7.4). The homogenate was centrifuged at $4000 \mathrm{rpm}$ for $15 \mathrm{~min}$ at $4{ }^{\circ} \mathrm{C}$, and the supernatant was kept at $-80^{\circ} \mathrm{C}$ till used.

\subsection{Biochemical Analysis}

\subsubsection{Determination of Uterine MDA Level}

Lipid peroxidation was assessed as thiobarbituric acid reacting substance and expressed as equivalents of MDA, using 1,1,3,3-tetramethoxypropane as a standard. The results were expressed as $\mathrm{nmol} / \mathrm{g}$ tissue [54].

\subsubsection{Determination of Uterine SOD Activity}

Briefly, uterine homogenates were mixed with Tris- $\mathrm{HCl}(\mathrm{pH} \mathrm{8.2)}$ and pyrogallol $(15 \mathrm{mM})$, and the absorbance of the sample was monitored against blank at $420 \mathrm{~nm}$ over a period of $3 \mathrm{~min}$. The activity of SOD was expressed as unit/g tissue [55]. One unit of SOD could be defined as the amount of enzyme that inhibits the oxidation of pyrogallol by $50 \%$.

\subsection{Macroscopic Examination and Histopathological Evaluation}

An examination of the uterus was performed to check for any macroscopic abnormalities. Regarding histopathological evaluation, the horn was dissected from each rat at the middle third, fixed in 10\% formalin for $24 \mathrm{~h}$, processed, and embedded in paraffin wax. Serial sections were prepared and stained with hematoxylin and eosin. The evaluation was conducted in a blind fashion using light microscopy.

Grading of histopathological changes was based on the following findings: glandular irregularity and crowdedness, epithelial lining hypertrophy and stratification, focal atypical cellular changes (loss of polarity, anisonucleosis, and prominent nucleoli), and stromal leukocytic infiltrate. The severity of the changes was graded semiquantitatively depending on the degree of the microscopic abnormalities as follow: ' 0 ' for no changes, ' + ' for mild changes, ' ++ ' for moderate changes, and ' +++ ' for severe changes.

\subsection{Immunohistochemistry}

Paraffin-embedded sections on positively charged slides were used for staining. Briefly, uterine sections were deparaffinized in xylene and rehydrated in a graded alcohol series. Endogenous peroxidase was blocked with $0.3 \%$ hydrogen peroxide for $30 \mathrm{~min}$ to inactivate endogenous peroxides. Antigen retrieval was conducted by microwaving in sodium citrate buffer ( $\mathrm{pH}$ 6.0). The sections were incubated with diluted primary antibodies $\operatorname{TNF} \alpha(1: 100$, overnight), survivin (1:50, for $1 \mathrm{~h})$, and cleaved caspase 3 (1:10, overnight). The sections were washed and then treated with biotinylated secondary antibody for $30 \mathrm{~min}$ at room temperature. Visualization was performed using 3,3'-diaminobenzidine chromogen, and Mayer's hematoxylin was used for counterstaining. To evaluate the cytoplasmic TNF $\alpha$ expression, the percentage of positive cells was graded as follow: 0 , no stained cells; $1, \leq 25 \%$ stained cells; $2,>25 \%$ and $\leq 50 \%$ stained cells; $3,>50 \%$ and $\leq 75 \%$ stained cells; $4,>75 \%$ stained cells [56]. Cytoplasmic survivin and cleaved caspase 
3 expression was evaluated as the percentage of positively stained cells and was considered positive when $\geq 10 \%$ of the cells showed cytoplasmic expression [57].

\subsection{Real-Time PCR}

Total RNA was extracted from homogenized uterine specimens using RiboZol RNA extraction reagent (AMRESCO, Solon, OH, USA) following the manufacturer's instructions. cDNAs were synthesized using RevertAid ${ }^{\mathrm{TM}}$ First Strand cDNA Synthesis kit (Thermo Fisher Scientific). Real-time PCR was performed using Maxima SYBR Green qPCR Master Mix (Thermo Fisher Scientific) with specific primers in the Real-Time PCR Detection System (Kapa Biosystems, Wilmington, MA, USA). The sets of primers used were as follows: IL10 forward primer, 5'-AAAGCAAGGCAGTGGAGCAG-3' and reverse primer, 5'-TCAAACTCATTCATGGCCTTGT-3' [58] and glyceraldehyde-3-phosphate dehydrogenase (GAPDH) forward primer, $5^{\prime}$-GTCGGTGTGAACGGATTTG- ${ }^{\prime}$ and reverse primer 5'-CTTGCCGTGGGTAGAGTCAT-3' [59]. The SYBR green data were analyzed with a relative quantification to GAPDH as a reference gene. Fold changes of IL10 mRNA levels were calculated using the comparative cycle threshold method [60]. The fold change in gene expression was scaled relative to the control, where control samples were set at a value of 1 .

\subsection{ELISA}

The inflammatory cytokine TNF $\alpha$ and the type II nuclear receptor PPAR $\gamma$ were determined in the uterine homogenate using TNF $\alpha$ and PPAR $\gamma$ ELISA kits according to the manufacturer's instructions.

\subsection{Statistical Analysis}

Data were analyzed by one-way ANOVA followed by Dunnett Multiple Comparison Test. The values were represented as means \pm SEM. Statistical analysis was conducted using GraphPad Prism software version 5 (San Diego, CA, USA). The differences were considered significant when the calculated $p$ value was less than 0.05 .

Author Contributions: Conceptualization, M.A.M. and M.M.M.R.; methodology, M.A.M., W.M.A., M.E.-H. and M.M.M.R.; formal analysis, M.A.M., W.M.A., M.E.-H. and M.M.M.R.; writing-original draft preparation, M.A.M., W.M.A., M.E.-H. and M.M.M.R.; writing-review and editing, M.A.M., W.M.A., M.E.-H. and M.M.M.R.; funding acquisition, M.A.M. All authors have read and agreed to the published version of the manuscript.

Funding: This research was funded by Deanship of Scientific Research at King Faisal University under Nasher Track (Grant No. 186230).

Institutional Review Board Statement: The study was conducted according to the guidelines of the Declaration of Helsinki and approved by the Institutional Research Ethics Committee of Faculty of Medicine, Minia University (716:12/2020).

Informed Consent Statement: Not applicable.

Data Availability Statement: Data are contained within the article or available upon reasonable request from the corresponding author.

Acknowledgments: The authors acknowledge the Deanship of Scientific Research at King Faisal University for the financial support under Nasher Track (Grant No. 186230).

Conflicts of Interest: The authors declare no conflict of interest.

\section{References}

1. Sengal, A.T.; Smith, D.; Rogers, R.; Snell, C.E.; Williams, E.D.; Pollock, P.M. Fibroblast Growth Factor Receptor 2 Isoforms Detected via Novel RNA ISH as Predictive Biomarkers for Progestin Therapy in Atypical Hyperplasia and Low-Grade Endometrial Cancer. Cancers 2021, 13, 1703. [CrossRef]

2. Sobczuk, K.; Sobczuk, A. New classification system of endometrial hyperplasia WHO 2014 and its clinical implications. Prz. Menopauzalny 2017, 16, 107-111. [CrossRef] [PubMed] 
3. Cancer Genome Atlas Research Network; Kandoth, C.; Schultz, N.; Cherniack, A.D.; Akbani, R.; Liu, Y.; Shen, H.; Robertson, A.G.; Pashtan, I.; Shen, R.; et al. Integrated genomic characterization of endometrial carcinoma. Nature 2013, 497, 67-73.

4. Modugno, F.; Ness, R.B.; Chen, C.; Weiss, N.S. Inflammation and endometrial cancer: A hypothesis. Cancer Epidemiol. Biomark. Prev. 2005, 14, 2840-2847. [CrossRef]

5. Smith, H.O.; Stephens, N.D.; Qualls, C.R.; Fligelman, T.; Wang, T.; Lin, C.Y.; Burton, E.; Griffith, J.K.; Pollard, J.W. The clinical significance of inflammatory cytokines in primary cell culture in endometrial carcinoma. Mol. Oncol. 2013, 7, 41-54. [CrossRef]

6. Jabbour, H.N.; Sales, K.J.; Catalano, R.D.; Norman, J.E. Inflammatory pathways in female reproductive health and disease. Reproduction 2009, 138, 903-919. [CrossRef] [PubMed]

7. Portt, L.; Norman, G.; Clapp, C.; Greenwood, M.; Greenwood, M.T. Anti-apoptosis and cell survival: A review. Biochim. Biophys. Acta 2011, 1813, 238-259. [CrossRef]

8. Landskron, G.; De la Fuente, M.; Thuwajit, P.; Thuwajit, C.; Hermoso, M.A. Chronic inflammation and cytokines in the tumor microenvironment. J. Immunol. Res. 2014, 2014, 149185. [CrossRef] [PubMed]

9. Altieri, D.C. Survivin and IAP proteins in cell-death mechanisms. Biochem. J. 2010, 430, 199-205. [CrossRef]

10. Kaur, K.; Sharma, A.K.; Dhingra, S.; Singal, P.K. Interplay of TNF-alpha and IL-10 in regulating oxidative stress in isolated adult cardiac myocytes. J. Mol. Cell. Cardiol. 2006, 41, 1023-1030. [CrossRef]

11. Li, X.F.; Ahmed, A. Expression of angiotensin II and its receptor subtypes in endometrial hyperplasia: A possible role in dysfunctional menstruation. Lab. Investig. 1996, 75, 137-145. [PubMed]

12. Delforce, S.J.; Lumbers, E.R.; Corbisier de Meaultsart, C.; Wang, Y.; Proietto, A.; Otton, G.; Scurry, J.; Verrills, N.M.; Scott, R.J.; Pringle, K.G. Expression of renin-angiotensin system (RAS) components in endometrial cancer. Endocr. Connect. 2017, 6, 9-19. [CrossRef]

13. Piastowska-Ciesielska, A.W.; Płuciennik, E.; Wójcik-Krowiranda, K.; Bieńkiewicz, A.; Bednarek, A.; Ochędalski, T. Analysis of the expression of angiotensin II type 1 receptor and VEGF in endometrial adenocarcinoma with different clinicopathological characteristics. Tumour Biol. 2012, 33, 767-774. [CrossRef] [PubMed]

14. Shan, T.; Shang, W.; Zhang, L.; Zhao, C.; Chen, W.; Zhang, Y.; Li, G. Effect of angiotensin-(1-7) and angiotensin II on the proliferation and activation of human endometrial stromal cells in vitro. Int. J. Clin. Exp. Pathol. 2015, 8, 8948-8957.

15. Matysiak-Burzyńska, Z.E.; Nowakowska, M.; Domińska, K.; Kowalska, K.; Płuciennik, E.; Piastowska-Ciesielska, A.W. Silencing of angiotensin receptor 1 interferes with angiotensin II oncogenic activity in endometrial cancer. J. Cell. Biochem. 2018, 119, 9110-9121. [CrossRef] [PubMed]

16. Ziaja, M.; Urbanek, K.A.; Kowalska, K.; Piastowska-Ciesielska, A.W. Angiotensin II and Angiotensin Receptors 1 and $2-$ Multifunctional System in Cells Biology, What Do We Know? Cells 2021, 10, 381. [CrossRef] [PubMed]

17. Koyama, N.; Nishida, Y.; Ishii, T.; Yoshida, T.; Furukawa, Y.; Narahara, H. Telmisartan induces growth inhibition, DNA double-strand breaks and apoptosis in human endometrial cancer cells. PLoS ONE 2014, 9, e93050. [CrossRef]

18. Kinoshita, J.; Fushida, S.; Harada, S.; Yagi, Y.; Fujita, H.; Kinami, S.; Ninomiya, I.; Fujimura, T.; Kayahara, M.; Yashiro, M.; et al. Local angiotensin II-generation in human gastric cancer: Correlation with tumor progression through the activation of ERK1/2, NF-kappaB and survivin. Int. J. Oncol. 2009, 34, 1573-1582. [CrossRef] [PubMed]

19. Wang, D.; Ning, W.; Xie, D.; Guo, L.; DuBois, R.N. Peroxisome proliferator-activated receptor delta confers resistance to peroxisome proliferator-activated receptor gamma-induced apoptosis in colorectal cancer cells. Oncogene 2012, 31, 1013-1023. [CrossRef]

20. Li, F.; Aljahdali, I.; Ling, X. Cancer therapeutics using survivin BIRC5 as a target: What can we do after over two decades of study? J. Exp. Clin. Cancer Res. 2019, 38, 368. [CrossRef] [PubMed]

21. Guzmán, E.A.; Pitts, T.P.; Tandberg, K.R.; Winder, P.L.; Wright, A.E. Discovery of Survivin Inhibitors Part 1: Screening the Harbor Branch Pure Compound Library. Mar. Drugs 2021, 19, 73. [CrossRef] [PubMed]

22. Ota, K.; Ito, K.; Suzuki, T.; Saito, S.; Tamura, M.; Hayashi, S.; Okamura, K.; Sasano, H.; Yaegashi, N. Peroxisome proliferatoractivated receptor gamma and growth inhibition by its ligands in uterine endometrial carcinoma. Clin. Cancer Res. 2006, 12, 4200-4208. [CrossRef]

23. Zhong, J.; Gong, W.; Lu, L.; Chen, J.; Lu, Z.; Li, H.; Liu, W.; Liu, Y.; Wang, M.; Hu, R.; et al. Irbesartan ameliorates hyperlipidemia and liver steatosis in type 2 diabetic $\mathrm{db} / \mathrm{db}$ mice via stimulating PPAR-gamma, AMPK/Akt/mTOR signaling and autophagy. Int. Immunopharmacol. 2017, 42, 176-184. [CrossRef] [PubMed]

24. Al-Kuraishy, H.M.; Al-Gareeb, A.I.; Al-Nami, M.S. Irbesartan Attenuates Gentamicin-induced Nephrotoxicity in Rats through Modulation of Oxidative Stress and Endogenous Antioxidant Capacity. Int. J. Prev. Med. 2020, 11, 16. [PubMed]

25. Helal, M.G.; Samra, Y.A. Irbesartan mitigates acute liver injury, oxidative stress, and apoptosis induced by acetaminophen in mice. J. Biochem. Mol. Toxicol. 2020, 34, e22447. [CrossRef]

26. Zhang, J.; Yang, L.; Ding, Y. Effects of irbesartan on phenotypic alterations in monocytes and the inflammatory status of hypertensive patients with left ventricular hypertrophy. BMC Cardiovasc. Disord. 2021, 21, 194. [CrossRef] [PubMed]

27. Pejić, S.; Todorović, A.; Stojiljković, V.; Kasapović, J.; Pajović, S.B. Antioxidant enzymes and lipid peroxidation in endometrium of patients with polyps, myoma, hyperplasia and adenocarcinoma. Reprod. Biol. Endocrinol. 2009, 7, 149. [CrossRef] [PubMed]

28. Das Gupta, S.; So, J.Y.; Wall, B.; Wahler, J.; Smolarek, A.K.; Sae-Tan, S.; Soewono, K.Y.; Yu, H.; Lee, M.J.; Thomas, P.E.; et al. Tocopherols inhibit oxidative and nitrosative stress in estrogen-induced early mammary hyperplasia in ACI rats. Mol. Carcinog. 2015, 54, 916-925. [CrossRef] [PubMed] 
29. Refaie, M.M.M.; El-Hussieny, M. The role of interleukin-1b and its antagonist (diacerein) in estradiol benzoate-induced endometrial hyperplasia and atypia in female rats. Fundam. Clin. Pharmacol. 2017, 31, 438-446. [CrossRef] [PubMed]

30. Olowofolahan, A.O.; Oyebode, O.T.; Olorunsogo, O.O. Methyl palmitate reversed estradiol benzoate-induced endometrial hyperplasia in female rats. Toxicol. Mech. Methods 2021, 31, 43-52. [CrossRef]

31. Lewandowski, Ł.; Kepinska, M.; Milnerowicz, H. The Copper-zinc superoxide dismutase activity in selected diseases. Eur. J. Clin. Investig. 2019, 49, e13036. [CrossRef]

32. Kim, S.M.; Kim, Y.G.; Jeong, K.H.; Lee, S.H.; Lee, T.W.; Ihm, C.G.; Moon, J.Y. Angiotensin II-induced mitochondrial Nox4 is a major endogenous source of oxidative stress in kidney tubular cells. PLoS ONE 2012, 7, e39739. [CrossRef]

33. Xing, L.; Fang, J.; Zhu, B.; Wang, L.; Chen, J.; Wang, Y.; Huang, J.; Wang, H.; Yao, X. Astragaloside IV protects against podocyte apoptosis by inhibiting oxidative stress via activating PPARgamma-Klotho-FoxO1 axis in diabetic nephropathy. Life Sci. 2021, 269, 119068. [CrossRef]

34. Kubyshkin, A.V.; Aliev, L.L.; Fomochkina, I.I.; Kovalenko, Y.P.; Litvinova, S.V.; Filonenko, T.G.; Lomakin, N.V.; Kubyshkin, V.A.; Karapetian, O.V. Endometrial hyperplasia-related inflammation: Its role in the development and progression of endometrial hyperplasia. Inflamm. Res. 2016, 65, 785-794. [CrossRef]

35. Mariappan, N.; Soorappan, R.N.; Haque, M.; Sriramula, S.; Francis, J. TNF-alpha-induced mitochondrial oxidative stress and cardiac dysfunction: Restoration by superoxide dismutase mimetic Tempol. Am. J. Physiol. Heart Circ. Physiol. 2007, 293, H2726-H2737. [CrossRef] [PubMed]

36. Yoshida, S.; Ono, M.; Shono, T.; Izumi, H.; Ishibashi, T.; Suzuki, H.; Kuwano, M. Involvement of interleukin-8, vascular endothelial growth factor, and basic fibroblast growth factor in tumor necrosis factor alpha-dependent angiogenesis. Mol. Cell. Biol. 1997, 17, 4015-4023. [CrossRef] [PubMed]

37. Purohit, A.; Newman, S.P.; Reed, M.J. The role of cytokines in regulating estrogen synthesis: Implications for the etiology of breast cancer. Breast Cancer Res. 2002, 4, 65-69. [CrossRef] [PubMed]

38. Abdelzaher, W.Y.; Bahaa, H.A.; Toni, N.D.M.; Sanad, A.S. Mechanisms underlying the protective effect of montelukast in prevention of endometrial hyperplasia in female rats. Int. Immunopharmacol. 2018, 62, 326-333. [CrossRef] [PubMed]

39. Sukhikh, G.T.; Zhdanov, A.V.; Davydova, M.P.; Slukina, T.V.; Chernukha, G.E.; Samoilova, T.E.; Smetnik, V.P. Disorders in cytokine gene expression in endometrial hyperplasia and effect of hormone therapy. Bull. Exp. Biol. Med. 2005, 139, 235-237. [CrossRef]

40. Abdel-Raheem, I.T.; Omran, G.A.; Katary, M.A. Irbesartan, an angiotensin II receptor antagonist, with selective PPAR-gammamodulating activity improves function and structure of chemotherapy-damaged ovaries in rats. Fundam. Clin. Pharmacol. 2015, 29, 286-298. [CrossRef]

41. Huang, G.; Cheng, P.; Ding, L.; Wang, L.; Hu, J.; Zhang, Y.; Cai, G.; Chen, M.; Shen, A.; Gao, S. Protective effect of Xin-Ji-Er-Kang on cardiovascular remodeling in high salt-induced hypertensive mice. Exp. Ther. Med. 2019, 17, 1551-1562. [CrossRef] [PubMed]

42. Lakshmi, S.P.; Reddy, A.T.; Banno, A.; Reddy, R.C. Airway Epithelial Cell Peroxisome Proliferator-Activated Receptor $\gamma$ Regulates Inflammation and Mucin Expression in Allergic Airway Disease. J. Immunol. 2018, 201, 1775-1783. [CrossRef] [PubMed]

43. Erkanli, S.; Kayaselcuk, F.; Kuscu, E.; Bagis, T.; Bolat, F.; Haberal, A.; Demirhan, B. Expression of survivin, PTEN and p27 in normal, hyperplastic, and carcinomatous endometrium. Int. J. Gynecol. Cancer 2006, 16, 1412-1418. [CrossRef]

44. He, F.; Zhang, W.; Zhang, H. Apoptotic signaling pathways in uteri of rats with endometrial hyperplasia induced by ovariectomy combined with estrogen. Gynecol. Obstet. Invest. 2013, 76, 51-56. [CrossRef] [PubMed]

45. Ohashi, H.; Takagi, H.; Oh, H.; Suzuma, K.; Suzuma, I.; Miyamoto, N.; Uemura, A.; Watanabe, D.; Murakami, T.; Sugaya, T.; et al. Phosphatidylinositol 3-kinase/Akt regulates angiotensin II-induced inhibition of apoptosis in microvascular endothelial cells by governing survivin expression and suppression of caspase-3 activity. Circ. Res. 2004, 94, 785-793. [CrossRef]

46. Amaya, K.; Ohta, T.; Kitagawa, H.; Kayahara, M.; Takamura, H.; Fujimura, T.; Nishimura, G.; Shimizu, K.; Miwa, K. Angiotensin II activates MAP kinase and NF-kappaB through angiotensin II type I receptor in human pancreatic cancer cells. Int. J. Oncol. 2004, 25, 849-856.

47. Bafford, R.; Sui, X.X.; Wang, G.; Conte, M. Angiotensin II and tumor necrosis factor-alpha upregulate survivin and Kruppel-like factor 5 in smooth muscle cells: Potential relevance to vein graft hyperplasia. Surgery 2006, 140, 289-296. [CrossRef]

48. Li, Z.; Yan, Z.; Xu, C.; Dong, Y.; Xiong, Y.; Dai, Y. Acetylshikonin attenuates angiotensin II-induced proliferation and motility of human brain smooth muscle cells by inhibiting Wnt/beta-catenin signaling. Hum. Cell 2018, 31, 242-250. [CrossRef]

49. Abdel-Hamid, H.A.; Zenhom, N.M.; Toni, N.D. Melatonin reduced endometrial hyperplasia induced by estradiol in female albino rats. Gen. Physiol. Biophys. 2019, 38, 63-71. [CrossRef]

50. Ager, E.I.; Wen, S.W.; Chan, J.; Chong, W.W.; Neo, J.H.; Christophi, C. Altered efficacy of AT1R-targeted treatment after spontaneous cancer cell-AT1R upregulation. BMC Cancer 2011, 11, 274. [CrossRef] [PubMed]

51. Clasen, R.; Schupp, M.; Foryst-Ludwig, A.; Sprang, C.; Clemenz, M.; Krikov, M.; Thöne-Reineke, C.; Unger, T.; Kintscher, U. PPARgamma-activating angiotensin type-1 receptor blockers induce adiponectin. Hypertension 2005, 46, 137-143. [CrossRef]

52. Michalczyk, K.; Niklas, N.; Rychlicka, M.; Cymbaluk-Płoska, A. The Influence of Biologically Active Substances Secreted by the Adipose Tissue on Endometrial Cancer. Diagnostics 2021, 11, 494. [CrossRef] [PubMed]

53. Afzal, S.; Sattar, M.A.; Johns, E.J.; Abdulla, M.H.; Akhtar, S.; Hashmi, F.; Abdullah, N.A. Interaction between irbesartan, peroxisome proliferator-activated receptor (PPAR- $\gamma$ ), and adiponectin in the regulation of blood pressure and renal function in spontaneously hypertensive rats. J. Physiol. Biochem. 2016, 72, 593-604. [CrossRef] [PubMed]

54. Buege, J.A.; Aust, S.D. Microsomal lipid peroxidation. Methods Enzymol. 1978, 52, 302-310. [PubMed] 
55. Marklund, S.; Marklund, G. Involvement of the superoxide anion radical in the autoxidation of pyrogallol and a convenient assay for superoxide dismutase. Eur. J. Biochem. 1974, 47, 469-474. [CrossRef] [PubMed]

56. de Matos, F.R.; de Moraes, M.; Nonaka, C.F.; de Souza, L.B.; de Almeida Freitas, R. Immunoexpression of TNF- $\alpha$ and TGF- $\beta$ in central and peripheral giant cell lesions of the jaws. J. Oral Pathol. Med. 2012, 41, 194-199. [CrossRef]

57. Zhang, H.Y.; Meng, X.; Du, Z.X.; Fang, C.Q.; Liu, G.L.; Wang, H.Q.; Deng, W.W. Significance of survivin, caspase-3, and VEGF expression in thyroid carcinoma. Clin. Exp. Med. 2009, 9, 207-213. [CrossRef]

58. Gonzalez, P.; Burgaya, F.; Acarin, L.; Peluffo, H.; Castellano, B.; Gonzalez, B. Interleukin-10 and interleukin-10 receptor-I are upregulated in glial cells after an excitotoxic injury to the postnatal rat brain. J. Neuropathol. Exp. Neurol. 2009, 68, 391-403. [CrossRef]

59. Strøm, C.C.; Aplin, M.; Ploug, T.; Christoffersen, T.E.; Langfort, J.; Viese, M.; Galbo, H.; Haunsø, S.; Sheikh, S.P. Expression profiling reveals differences in metabolic gene expression between exercise-induced cardiac effects and maladaptive cardiac hypertrophy. FEBS J. 2005, 272, 2684-2695. [CrossRef]

60. VanGuilder, H.D.; Vrana, K.E.; Freeman, W.M. Twenty-five years of quantitative PCR for gene expression analysis. Biotechniques 2008, 44, 619-626. [CrossRef] 